\title{
Evaluation of Subclinical Myocardial Dysfunction Using Tissue Doppler Imaging Echocardiography in Children with Non-Alcoholic Fatty Liver Disease
}

\author{
ESSAM M.E. ELGENDY, M.Sc.*; MOHIEE EL-DEEN A. AWAD, M.D.*; OSAMA A. TOLBA, M.D.* and \\ AMAL S. ELBENDARY, M.D.** \\ The Departments of Pediatric* and Clinical Pathology**, Faculty of Medicine, Tanta University
}

\begin{abstract}
Background: Pediatric Non-Alcoholic Fatty Liver Disease (NAFLD) is a global health problem worldwide and is considered the most common cause of chronic liver disease in pediatrics. Both NAFLD and heart failure are obesity-related conditions with high cardiovascular morbidity and mortality that have reached epidemic proportions.

Aim of Study: Evaluate subclinical myocardial dysfunction using Tissue Doppler imaging Echocardiography in a group of overweight/obese children and adolescents with NAFLD.

Patients and Methods: This prospective case-control study was carried out upon 80 children (40 cases with NAFLD, 20 cases obese without NAFLD and 20 healthy controls). Diagnosis of NAFLD was based on the finding of hepatic steatosis detected by abdominal ultrasonography. These children underwent full examination, lab investigations and TDI echocardiography.

Results: Using conventional echocardiography mean value of LV mass was significantly higher in patients with NAFLD compared to controls. Using TDI mean values of MPI was significantly higher in patients compared to controls, whereas other parameter showed no significant difference. Left ventricular mass by echo showed significant increase as the hepatic steatosis was advancing in severity.

Conclusion: Patients with NAFLD have evidence of subclinical myocardial dysfunction using TDI echocardiography. Although the TDI provides new insight into alterations in LV structure and function related to IR in NAFLD patients, it cannot be used for differentiation of steatosis grading.
\end{abstract}

Key Words: Non alcoholic fatty liver disease - Left ventricular mass - Tissue Doppler imaging - Myocardial performance index.

Correspondence to: Dr. Essam M.E. Elgendy, The Department of Pediatric, Faculty of Medicine, Tanta University

\section{Introduction}

PARALLELING the epidemic of childhood obesity, pediatric Non-Alcoholic Fatty Liver Disease (NAFLD) has emerged as a growing global health problem worldwide and is considered the most common cause of chronic liver disease in pediatrics, affecting an alarming number $(38 \%)$ of obese children [1]. Both NAFLD and heart failure are obesity-related conditions with high cardiovascular morbidity and mortality that have reached epidemic proportions [2] studies have shown that mortality among patients with NAFLD is higher than that in general population, mainly due to Cardiovascular Disease (CVD) and liver dysfunction [3] . In fact, patients with NAFLD are more likely to die from complications of CVD than from liver-related death [4]. Growing evidence suggests that NAFLD is an independent risk factor for CVD and is associated with impaired endothelial function, [5] a higher prevalence of vulnerable coronary plaques [6] and with unfavorable levels of markers of subclinical atherosclerotic disease, including increased carotid intima media thicknes [7] and coronary artery calcification [8]. Given that NAFLD and metabolic syndrome features often coexist, any relationship between NAFLD and cardiac remodeling and dysfunction may be moderated by visceral adipose tissue volume, obesity, or other cardiometabolic risk factors [9].

Conventional echocardiography provides assessment of the cardiac structure, function and hemodynamics. TDI is another useful echocardiographic technique employing the Doppler principle to measure the velocity of myocardial segments and other cardiac structures which is load independent. 


\section{Patients and Methods}

This prospective case-control study was carried out upon three groups of children. The first group comprised 40 overweight/obese children and adolescents with ultrasound proven NAFLD, the second group involved 20 overweight/obese children and adolescents of matched age, sex, and BMI with normal levels of liver enzymes and lipid profile, with no evidence of steatosis by ultrasonography, whereas the third group included 20 healthy children of matched age and sex as a healthy control group. Diagnosis of NAFLD was based on the finding of hepatic steatosis detected by abdominal ultrasonography and appropriate exclusion of other causes of fatty liver. Children were selected from those attending the Outpatient Endocrinology Clinic of Pediatric Department at Tanta University Hospital during the period from June, 2017 to June, 2018.

Inclusion criteria: Overweight and obese children and adolescents with and without ultrasound proven NAFLD.

Exclusion criteria: Patients with known disorders to cause fatty liver, e.g. diabetes mellitus, glycogen storage disease and Wilson's disease, any patient with syndromatic obesity, patients receiving long term use of drugs known to cause steatosis, e.g. gulcocorticoids, patients with any other chronic liver disease such as viral hepatitis, autoimmune hepatitis, etc. were excluded by performing the appropriate investigations, children with congenital and those with acquired cardiac diseases and children with other systemic also diseases, metabolic or genetic diseases.

All the children in the study were subjected to detailed history, full clinical examination, laboratory investigations in the form of liver enzymes, blood cholesterol, triglycerides, LDL, HDL, fasting blood glucose level fasting serum insulin level, calculation of IR Troponin I (cardiac marker).

Abdominal ultrasonography: All patients were examined by abdominal ultrasound to detect the presence of liver fatty infiltration and to assess semi-quantitatively the degree of steatosis.

Echocardiographic examinations: Conventional, Tissue Doppler echocardiographic examination.

\section{Equipment:}

1- Machine: Echocardiographic studies were performed using a commercially available ultra- sound transducer and equipment (Vivid 7 or Vivid 9, GE Healthcare, Horten, Norway).

2- Transducers: Data acquisition was performed with a $3.5 \mathrm{MHz}$ transducer, S7 and V3 matrix real-time 3 dimensional probes.

3- Workstation: Digital loops were stored on the hard disc of the echocardiography machine and transferred to a workstation (Echo PAC PC, 113; GE, and Horten, Norway) for offline analysis.

\section{Technique:}

\section{1- Conventional echocardiographic examination:}

Mitral inflow velocity was assessed using Pulsed-Wave (PW) Doppler in the apical fourchamber view, with a $3 \mathrm{~mm}$ sample placed between the tips of the mitral leaflets. Diastolic indices that included mitral peak early LV filling velocity $(\mathrm{E})$, peak late atrial filling velocity (A), were measured offline from the obtained recordings of inflow velocity pattern $(\mathrm{cm} / \mathrm{s})$ and averaged over 3 cardiac cycles. The ratios of trans-mitral early to late diastolic flow velocity (E/A ratio) as a measure of LV diastolic function were calculated [10].

\section{2-Pulsed wave tissue Doppler imaging (PW-TDI):}

A- Mitral valve annular velocities: Annular velocities by PW-TDI were obtained from the apical 4-chamber view during quiet respiration by placing a sample volume of $5.5 \mathrm{~mm}$ at the lateral margin of the mitral valve annuli. The peak mitral annular systolic velocity (S), the peak early mitral annular diastolic velocities $\left(\mathrm{E}^{\prime}, \mathrm{cm} / \mathrm{s}\right)$ and peak late mitral annular diastolic velocities $\left(\mathrm{A}^{\prime}, \mathrm{cm} / \mathrm{s}\right)$ were measured offline from the time-myocardial velocity waveforms of 3 consecutive cardiac cycles and an average were recorded. The ratios of mitral early to late annular diastolic velocity (E'/A' ratio) as a measure of LV diastolic function was calculated [11].

B- Myocardial Performance Index (MPI) calculation: The intervals (a') between the end of the late diastolic annular velocity and the onset of the early diastolic annular velocity were equal to the sum of the isovolumetric contraction time (ICT), Isovolumetric Relaxation Time (IRT), and Ejection Time (ET). The ET ( $\left.b^{\prime}\right)$ was measured as the duration of the systolic annular velocity (S). The sum of the ICT and IRT was obtained by subtracting (b') from (a'). Then the LV Tei index was calculated as $\left(a^{\prime}-b^{\prime}\right) / b^{\prime}$. All interval measurements in milliseconds were performed by TDI within one cardiac cycle [12]. 


\section{Results}

This prospective case-control study was carried out upon 80 children (40 cases with NAFLD, 20 cases obese without NAFLD and 20 healthy controls).

The mean values of age were significantly higher in obese patients with NAFLD compared to controls, there was insignificant male predominance in obese children and adolescents with NAFLD compared to controls and the frequency of patients with positive family history of obesity was significantly higher in obese patients (with and without NAFLD compared to controls.

The mean value of height was statistically insignificant between patients and controls, mean values of weight, BMI and WC were significantly higher in obese children with and without NAFLD compared to controls. But there were no differences between obese patients with and those without NAFLD.

The frequency of patients with acanthosis nigricans was significantly higher in obese children and adolescent with NAFLD compared to those without NAFLD, mean values of diastolic blood pressure were significantly higher in obese children and adolescent with NAFLD compared to controls with no difference between patients with and without NAFLD.

Mean values of ALT and GGT were significantly higher in obese patients with NAFLD compared to controls. But there were no difference between obese patients with and without NAFLD.

- Mean values of total cholesterol were significantly higher in obese patients with and without NAFLD compared to controls.

- Mean values of TG were significantly higher in obese patients with NAFLD compared to obese patients without NAFLD and to controls.

- Mean values of LDL were significantly higher in obese patients with NAFLD compared to controls.

- Mean value of HDL was significantly lower in obese patients with and without NAFLD compared to controls.

Mean values of fasting serum insulin level and insulin resistance were significantly higher in obese patients with and without NAFLD compared to controls.
Serum troponin I show no significant differences between patients and controls.

\section{Analysis of echocardiographic results:}

A- Conventional echocardiography: Mean values of LV Mass were significantly higher in obese children and adolescents with NAFLD compared to the controls, whereas mean values of EF show non-significant difference between patients and controls.

$B$ - Tissue Doppler imaging: Mean value of mitral annulus systolic velocity ( $\left.\mathrm{S}^{\prime}\right)$ and $\mathrm{E}^{\prime} / \mathrm{A}^{\prime}$ ratio shows insignificant difference between obese children and adolescents (with and without NAFLD) and controls.

Mean value of MPI was significantly higher in obese patients with and without NAFLD compared to controls. But there were no difference between obese patients with and without NAFLD.

There was semi-parallel increase in the percentage of cases with many abnormal laboratory data, with advance of the degree of hepatic echogenicity.

Tissue Doppler Imaging (TDI) data of NAFLD patients showed insignificant differences as the hepatic steatosis was advancing in severity. But LV mass by conventional echo showed significant increase as the hepatic steatosis was advancing in severity.

Table (1): Age, sex and family history of obesity of obese children and adolescents (with and without NAFLD) and the control group.

\begin{tabular}{|c|c|c|c|c|c|c|c|}
\hline \multirow{3}{*}{ Variables } & \multicolumn{6}{|c|}{$\begin{array}{l}\text { The studied children and adolescents } \\
\qquad(\mathrm{n}=80)\end{array}$} & \multirow{3}{*}{$\chi^{2}$} \\
\hline & \multicolumn{2}{|c|}{$\begin{array}{l}\text { Obese } \\
\text { with } \\
\text { NAFLD } \\
(\mathrm{n}=40)\end{array}$} & \multicolumn{2}{|c|}{$\begin{array}{c}\text { Obese } \\
\text { without } \\
\text { NAFLD } \\
(\mathrm{n}=20)\end{array}$} & \multicolumn{2}{|c|}{$\begin{array}{l}\text { Control } \\
\text { group } \\
(n=20)\end{array}$} & \\
\hline & $\mathrm{N}$ & $\%$ & $\mathrm{~N}$ & $\%$ & $\mathrm{~N}$ & $\%$ & \\
\hline $\begin{array}{l}\text { Age years: } \\
\text { - Range } \\
\text { - Mean } \pm \mathrm{SD}\end{array}$ & $\begin{array}{l}5.50 \\
12.0\end{array}$ & $\begin{array}{l}6.00 \\
\pm 2.66\end{array}$ & $\begin{array}{l}3.5 \\
9.0\end{array}$ & $\begin{array}{l}16.50 \\
2.96\end{array}$ & $\begin{array}{l}4.5 \\
8.8\end{array}$ & $\begin{array}{l}16.00 \\
=3.16\end{array}$ & \\
\hline $\begin{array}{l}\text { F-value } \\
p\end{array}$ & & & & 16 & & & \\
\hline $\begin{array}{l}\text { Sex: } \\
\quad \text { - Males } \\
\text { - Females }\end{array}$ & $\begin{array}{r}24 \\
16\end{array}$ & $\begin{array}{l}60.0 \\
40.0\end{array}$ & $\begin{array}{l}11 \\
9\end{array}$ & $\begin{array}{l}55.0 \\
45.0\end{array}$ & $\begin{array}{l}9 \\
11\end{array}$ & $\begin{array}{l}45.0 \\
5.0\end{array}$ & $\begin{array}{l}0.545 \\
1.212\end{array}$ \\
\hline $\begin{array}{l}\text { Family history } \\
\text { of obesity: } \\
\text { - Positive } \\
\text { - Negative }\end{array}$ & $\begin{array}{l}25 \\
15\end{array}$ & $\begin{array}{l}62.5 \\
37.5\end{array}$ & $\begin{array}{l}6 \\
14\end{array}$ & $\begin{array}{l}30.0 \\
70.0\end{array}$ & $\begin{array}{l}0 \\
20\end{array}$ & $\begin{array}{l}0 \\
100\end{array}$ & $\begin{array}{l}22.804 \\
0.0001 *\end{array}$ \\
\hline
\end{tabular}


Table (2): Anthropometric measures of obese children and adolescents (with and without NAFLD) and the control group.

\begin{tabular}{|c|c|c|c|c|}
\hline \multirow[b]{2}{*}{ Variables } & \multicolumn{3}{|c|}{$\begin{array}{l}\text { The studied children and adolescents } \\
\qquad(\mathrm{n}=80)\end{array}$} & \multirow{2}{*}{$\begin{array}{c}\text { F- } \\
\text { value } \\
p\end{array}$} \\
\hline & $\begin{array}{l}\text { Obese with NAFLD } \\
(\mathrm{n}=40) \mathrm{GI}\end{array}$ & $\begin{array}{l}\text { Obese without NAFLD } \\
\qquad(\mathrm{n}=20) \text { GII }\end{array}$ & $\begin{array}{l}\text { Control group } \\
(\mathrm{n}=20) \text { GIII }\end{array}$ & \\
\hline \multicolumn{5}{|l|}{ Height $(\mathrm{cm})$ : } \\
\hline • Range & $97.00-173.00$ & $96.50-163.00$ & $97.00-170.00$ & 1.912 \\
\hline • Mean \pm SD & $142.00 \pm 17.68$ & $134.30 \pm 17.56$ & $135.52 \pm 18.30$ & 0.155 \\
\hline \multicolumn{5}{|l|}{ Weight $(\mathrm{kg})$ : } \\
\hline • Range & $30.00-150.00$ & $25.40-103.00$ & $16.00-58.00$ & 16.744 \\
\hline - Mean \pm SD & $69.90 \pm 29.55$ & $55.35 \pm 21.11$ & $31.87 \pm 10.07$ & $0.0001 *$ \\
\hline $\begin{array}{l}\text { - Scheffe test } \\
\cdot p\end{array}$ & \multicolumn{3}{|c|}{ I vs. II $\&$ III $p=0.093 \& 0.0001^{*}$} & \\
\hline \multicolumn{5}{|l|}{ BMI: } \\
\hline • Range & $22.30-54.40$ & $22.90-40.20$ & $13.20-20.00$ & 50.666 \\
\hline - Mean \pm SD & $32.85 \pm 7.17$ & $30.10 \pm 5.28$ & $17.04 \pm 1.91$ & $0.0001 *$ \\
\hline $\begin{array}{l}\cdot \text { Scheffe test } \\
\cdot p\end{array}$ & \multicolumn{3}{|c|}{ I vs. II \& III $p=0.231 \& 0.0001 *$} & \\
\hline \multicolumn{5}{|l|}{$W C(\mathrm{~cm}):$} \\
\hline • Range & $68.00-140.00$ & $55.50-118.00$ & $24.00-62.00$ & 54.501 \\
\hline • Mean \pm SD & $93.23 \pm 16.61$ & $84.59 \pm 16.94$ & $47.30 \pm 14.75$ & $0.0001 *$ \\
\hline $\begin{array}{l}\text { - Scheffe test } \\
\cdot p\end{array}$ & \multicolumn{3}{|c|}{ I vs. II $\&$ III $p=0.159 \& 0.0001^{*}$} & \\
\hline
\end{tabular}

Table (3): Clinical data of obese children and adolescents (with and without NAFLD) and the control group.

\begin{tabular}{|c|c|c|c|c|}
\hline \multirow{3}{*}{ Variables } & \multicolumn{3}{|c|}{$\begin{array}{l}\text { The studied children and adolescents } \\
\qquad(\mathrm{n}=80)\end{array}$} & \multirow{3}{*}{$\begin{array}{l}\chi^{2} \\
p\end{array}$} \\
\hline & $\begin{array}{c}\text { Obese } \\
\text { with } \\
\text { NAFLD } \\
(\mathrm{n}=40)\end{array}$ & $\begin{array}{c}\text { Obese } \\
\text { without } \\
\text { NAFLD } \\
(\mathrm{n}=20)\end{array}$ & $\begin{array}{l}\text { Control } \\
\text { group } \\
(n=20)\end{array}$ & \\
\hline & $\mathrm{N} \quad \%$ & $\mathrm{~N} \quad \%$ & $\mathrm{~N} \% \mathbf{0}$ & \\
\hline Acanthosis & 2767.5 & $13 \quad 65.0$ & 0 & 26.700 \\
\hline $\begin{array}{l}\text { Systolic BP: } \\
\text { - Range } \\
\text { - Mean } \pm \mathrm{SD}\end{array}$ & $\begin{array}{l}80.0-145.00 \\
104.62 \pm 15.74\end{array}$ & $\begin{array}{l}80.00-140.00 \\
100.25 \pm 16.26\end{array}$ & $\begin{array}{l}80.00-120.00 \\
96.75 \pm 11.39\end{array}$ & $0.0001 *$ \\
\hline $\begin{array}{l}\cdot \mathrm{F} \text {-value } \\
\cdot p\end{array}$ & & $\begin{array}{l}1.959 \\
0.148\end{array}$ & & \\
\hline $\begin{array}{l}\text { Diastolic BP: } \\
\text { - Range } \\
\text { - Mean } \pm \mathrm{SD}\end{array}$ & $\begin{array}{l}50.00-90.00 \\
70.00-12.14\end{array}$ & $\begin{array}{l}50.00-80.00 \\
64.75 \pm 11.52\end{array}$ & $\begin{array}{l}50.00-75.00 \\
61.50 \pm 7.27\end{array}$ & \\
\hline $\begin{array}{l}\cdot \mathrm{F} \text {-value } \\
\cdot p\end{array}$ & & $\begin{array}{l}4.361 \\
0.016^{*}\end{array}$ & & \\
\hline $\begin{array}{l}\text { Scheffe test } \\
p\end{array}$ & $\begin{array}{r}\text { I vs. II \& } \\
\text { II }\end{array}$ & $\begin{array}{l}\text { III } p=0.2248 \\
\text { vs. III, } p=0.64\end{array}$ & $\begin{array}{l}0.022 * \\
7\end{array}$ & \\
\hline
\end{tabular}

Table (4): Liver enzymes among obese children and adolescents (with and without NAFLD) and the control group.

\begin{tabular}{|c|c|c|c|c|}
\hline \multirow{2}{*}{ Variables } & \multicolumn{3}{|c|}{$\begin{array}{l}\text { The studied children and adolescents } \\
\qquad(\mathrm{n}=80)\end{array}$} & \multirow{2}{*}{$\begin{array}{c}\text { F- } \\
\text { value } \\
p\end{array}$} \\
\hline & $\begin{array}{l}\text { Obese with } \\
\text { NAFLD } \\
(\mathrm{n}=40) \text { GI }\end{array}$ & $\begin{array}{c}\text { Obese without } \\
\text { NAFLD } \\
(\mathrm{n}=20) \mathrm{GII}\end{array}$ & $\begin{array}{c}\text { Control } \\
\text { group } \\
(\mathrm{n}=20) \text { GIII }\end{array}$ & \\
\hline \multicolumn{5}{|l|}{$A S T(U / L):$} \\
\hline - Range & $7.00-96.00$ & $6.00-40.00$ & $6.00-55.00$ & 2.803 \\
\hline - Mean \pm SD & $31.00 \pm 23.33$ & $22.00 \pm 2.93$ & $20.00 \pm 11.50$ & 0.067 \\
\hline \multicolumn{5}{|l|}{$A L T(U / L):$} \\
\hline • Range & $10.00-58.00$ & $8.00-46.00$ & $8.00-35.00$ & 6.439 \\
\hline - Mean \pm SD & $29.00 \pm 13.37$ & $24.00 \pm 10.46$ & $19.00 \pm 7.84$ & $0.003 *$ \\
\hline $\begin{array}{l}\cdot \text { Scheffe test } \\
\cdot p\end{array}$ & \multicolumn{3}{|c|}{ I vs. II $\&$ III $p=0.262 \& 0.003 *$} & \\
\hline \multicolumn{5}{|l|}{$G G T(U / L):$} \\
\hline • Range & $11.00-22.00$ & $6.00-23.00$ & $5.00-18.00$ & 9.920 \\
\hline - Mean \pm SD & $15.00 \pm 2.73$ & $14.00 \pm 4.67$ & $11.00 \pm 4.01$ & $0.0001 *$ \\
\hline $\begin{array}{l}- \text { Scheffe test } \\
\cdot p\end{array}$ & \multicolumn{3}{|c|}{$\begin{array}{l}\text { I vs. II } \& \text { III } p=0.385 \& 0.0001^{*} \\
\text { II vs. III, } p=0.034 *\end{array}$} & \\
\hline 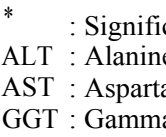 & $\begin{array}{l}\text { cant }(p<0.05) \text {. } \\
\text { e Transferase. } \\
\text { ate Transferase } \\
\text { a Glutamyl Tra }\end{array}$ & ansferase & & \\
\hline
\end{tabular}


Table (5): Lipid profile among obese children and adolescents (with and without NAFLD) and the control group.

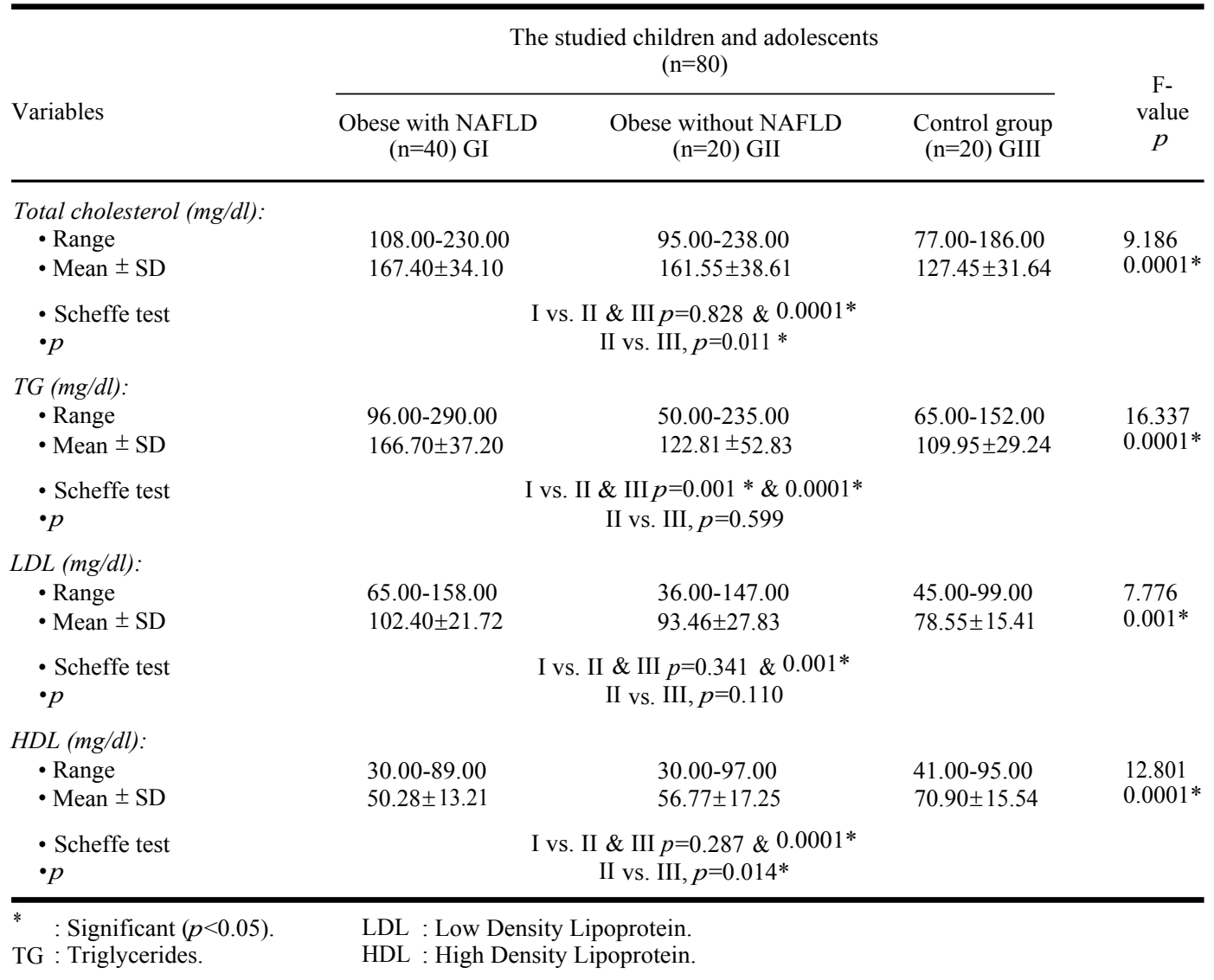

Table (6): Fasting blood sugar, fasting serum insulin level and insulin resistance among obese children and adolescents (with and without NAFLD) and the control group.

\begin{tabular}{|c|c|c|c|c|}
\hline \multirow[b]{2}{*}{ Variables } & \multicolumn{3}{|c|}{$\begin{array}{l}\text { The studied children and adolescents } \\
\qquad(\mathrm{n}=80)\end{array}$} & \multirow{2}{*}{$\begin{array}{c}\text { F- } \\
\text { value } \\
p\end{array}$} \\
\hline & $\begin{array}{l}\text { Obese with NAFLD } \\
\qquad(\mathrm{n}=40) \mathrm{GI}\end{array}$ & $\begin{array}{l}\text { Obese without NAFLD } \\
\qquad(\mathrm{n}=20) \mathrm{GII}\end{array}$ & $\begin{array}{l}\text { Control group } \\
(\mathrm{n}=20) \text { GIII }\end{array}$ & \\
\hline \multicolumn{5}{|c|}{ Fasting blood sugar (mg/dl): } \\
\hline • Range & $60.00-115.00$ & $68.00-117.00$ & $68.00-112.00$ & 0.619 \\
\hline - Mean \pm SD & $88.30 \pm 13.29$ & $89.10 \pm 12.20$ & $84.95 \pm 12.60$ & 0.541 \\
\hline \multicolumn{5}{|c|}{ Fasting serum insulin $(m c l u / m l):$} \\
\hline • Range & $3.00-24.00$ & $4.00-28.00$ & $3.00-14.00$ & 22.308 \\
\hline - Mean $\pm \mathrm{SD}$ & $15.37 \pm 5.07$ & $13.80 \pm 5.15$ & $6.93 \pm 3.01$ & $0.0001 *$ \\
\hline - Scheffe test & \multicolumn{3}{|c|}{ I vs. II $\&$ III $p=0.474 \& 0.0001 *$} & \\
\hline$\cdot p$ & \multicolumn{3}{|c|}{ II vs. III, $p=0.0001 *$} & \\
\hline \multicolumn{5}{|l|}{ Insulin resistance: } \\
\hline - Range & $2.88-5.70$ & $2.43-6.44$ & $0.57-3.04$ & 114.339 \\
\hline - Mean \pm SD & $4.42 \pm 0.71$ & $4.40 \pm 0.84$ & $1.47 \pm 0.75$ & $0.0001 *$ \\
\hline - Scheffe test & \multicolumn{3}{|c|}{ I vs. II \& III $p=0.993 \& 0.0001 *$} & \\
\hline$\cdot p$ & \multicolumn{3}{|c|}{ II vs. III, $p=0.0001 *$} & \\
\hline
\end{tabular}

*: Significant $(p<0.05)$. 
Table (7): Serum Troponin I among obese children and adolescents (with and without NAFLD) and the control group.

\begin{tabular}{lccc}
\hline & \multicolumn{3}{c}{ The studied children and adolescents } \\
Variables & $\begin{array}{c}\text { Obese with } \\
\text { NAFLD } \\
(\mathrm{n}=40) \mathrm{GI}\end{array}$ & $\begin{array}{c}\text { Obese without } \\
\text { NAFLD } \\
(\mathrm{n}=20) \mathrm{GII}\end{array}$ & $\begin{array}{c}\text { Control } \\
\text { group } \\
(\mathrm{n}=20) \mathrm{GIII}\end{array}$ \\
\cline { 2 - 4 } & & & \\
\hline $\begin{array}{l}\text { Serum Tropoin I }(\mathrm{ng} / \mathrm{ml}): \\
\bullet \text { Range }\end{array}$ & $0.06-0.19$ & $0.04-0.19$ & $0.05-0.19$ \\
$\bullet$ Mean $\pm \mathrm{SD}$ & $0.12 \pm 0.03$ & $0.12 \pm 0.04$ & $0.13 \pm 0.03$ \\
$\bullet \chi^{2}$ & & 0.354 & \\
$\bullet p$ & & 0.838 & \\
\hline
\end{tabular}

$\chi 2$ value of Kruskal Wallis test.

Table (8): Left ventricular mass (LV Mass) and Ejection Fraction (EF) measured by conventional echocardiography among obese children and adolescents (with and without NAFLD) versus the control group.

\begin{tabular}{|c|c|c|c|}
\hline \multirow{2}{*}{$\begin{array}{l}\text { Conventional } \\
\text { echocardiographic } \\
\text { finding }\end{array}$} & \multicolumn{3}{|c|}{ The studied children and adolescents $(n=80)$} \\
\hline & $\begin{array}{l}\text { Obese with } \\
\text { NAFLD } \\
(n=40)\end{array}$ & $\begin{array}{l}\text { Obese without } \\
\text { NAFLD } \\
(\mathrm{n}=20)\end{array}$ & $\begin{array}{l}\text { Control } \\
\text { group } \\
(\mathrm{n}=20)\end{array}$ \\
\hline \multicolumn{4}{|l|}{ LV mass: } \\
\hline - Range & $73-145$ & $74-123$ & $70.00-100.00$ \\
\hline - Mean \pm SD & $105.15 \pm 17.03$ & $99.05 \pm 16.12$ & $89.80 \pm 8.80$ \\
\hline - F-value & & 6.857 & \\
\hline$\cdot p$ & & $0.002 *$ & \\
\hline - Scheffe test & I vs. I & $\&$ III $p=0.345 \&$ & $0.002 *$ \\
\hline$\bullet p$ & & I vs. III, $p=0.163$ & \\
\hline \multicolumn{4}{|l|}{$E F(\%):$} \\
\hline - Range & $40.00-70.00$ & $42.00-68.00$ & $42.00-66.00$ \\
\hline - Mean \pm SD & $52.80 \pm 5.95$ & $51.85 \pm 6.94$ & $53.60 \pm 6.23$ \\
\hline - F-value & & 0.390 & \\
\hline$\cdot p$ & & 0.679 & \\
\hline
\end{tabular}

*: Significant $(p<0.05)$.

Table (9): Mitral annulus systolic velocity (S'), MPI and E'/A' ratio measured by tissue Doppler imaging among obese children and adolescents (with and without NAFLD) versus the control group.

\begin{tabular}{|c|c|c|c|}
\hline \multirow[b]{2}{*}{$\begin{array}{l}\text { Tissue Doppler } \\
\text { Imaging (TDI) }\end{array}$} & \multicolumn{3}{|c|}{$\begin{array}{l}\text { The studied children and } \\
\text { adolescents }(\mathrm{n}=80)\end{array}$} \\
\hline & $\begin{array}{l}\text { Obese with } \\
\text { NAFLD } \\
(n=40)\end{array}$ & $\begin{array}{l}\text { Obese without } \\
\text { NAFLD } \\
(n=20)\end{array}$ & $\begin{array}{l}\text { Control } \\
\text { group } \\
(\mathrm{n}=20)\end{array}$ \\
\hline \multicolumn{4}{|c|}{ Mitral annulus systolic } \\
\hline \multicolumn{4}{|c|}{ velocity $\left(S^{\prime}\right)(\mathrm{cm} / \mathrm{sec})$ : } \\
\hline - Range & $6.00-8.00$ & $6.00-8.00$ & $6.00-8.00$ \\
\hline - Mean \pm SD & $6.95 \pm 0.78$ & $6.60 \pm 0.82$ & $6.75 \pm 0.64$ \\
\hline • F- value & & 1.505 & \\
\hline$\cdot p$ & & 0.228 & \\
\hline \multicolumn{4}{|l|}{$E^{\prime} / A^{\prime}$ ratio: } \\
\hline - Range & $0.80-1.90$ & $1.10-1.90$ & $1.10-1.90$ \\
\hline - Mean \pm SD & $1.60 \pm 0.24$ & $1.58 \pm 0.28$ & $1.54 \pm 0.22$ \\
\hline - F-value & & 0.389 & \\
\hline$\cdot p$ & & 0.679 & \\
\hline \multicolumn{4}{|l|}{ MPI: } \\
\hline - Range & $0.16-0.90$ & $0.40-0.80$ & $0.30-0.50$ \\
\hline - Mean \pm SD & $0.56 \pm 0.15$ & $0.57 \pm 0.12$ & $0.37 \pm 0.07$ \\
\hline$\bullet \chi 2$ value & \multicolumn{3}{|c|}{16.240} \\
\hline$\cdot p$ & \multicolumn{3}{|c|}{$0.0001 *$} \\
\hline • Z-value & \multicolumn{3}{|c|}{ I vs. II $\&$ III $p=0.945 \& 0.0001 *$} \\
\hline$\cdot p$ & \multicolumn{3}{|c|}{ II vs. III, $p=0.0001 *$} \\
\hline
\end{tabular}

Table (10): Frequency of cases with abnormal laboratory data in relation to the degree of hepatic steatosis.

\begin{tabular}{|c|c|c|c|c|c|c|c|}
\hline \multirow{3}{*}{ Abnormal laboratory data } & \multicolumn{4}{|c|}{$\begin{array}{l}\text { Frequency of cases with abnormal } \\
\text { laboratory data in relation to the } \\
\text { degree of hepatic steatosis }(n=40)\end{array}$} & \multirow{3}{*}{ Total } & \multirow{3}{*}{$\chi^{2}$} & \multirow{3}{*}{$p$} \\
\hline & \multicolumn{2}{|c|}{$\begin{array}{c}\text { Mild } \\
(\text { Grade I) } \\
(\mathrm{n}=24)\end{array}$} & \multicolumn{2}{|c|}{$\begin{array}{l}\text { Moderate \& severe } \\
\text { (Grade II \& III) } \\
\quad(n=16)\end{array}$} & & & \\
\hline & $\mathrm{N}$ & $\%$ & $\mathrm{~N}$ & $\%$ & & & \\
\hline Hypercholesterolemia & 6 & 25.0 & 2 & 12.5 & $8 \quad(20 \%)$ & 0.938 & 0.333 \\
\hline Hypertriglyceridemia & 5 & 20.8 & 5 & 31.3 & $10(25 \%)$ & 0.556 & 0.456 \\
\hline Elevated LDL & 5 & 20.8 & 0 & 0 & $5 \quad(12.5 \%)$ & 3.810 & 0.051 \\
\hline Low HDL & 4 & 16.7 & 3 & 18.8 & $7 \quad(17.5 \%)$ & 0.029 & 0.865 \\
\hline Elevated ALT & 2 & 8.3 & 4 & 25.0 & $6 \quad(15 \%)$ & 2.092 & 0.148 \\
\hline Elevated AST & 4 & 16.7 & 4 & 25.0 & $8 \quad(20 \%)$ & 0.417 & 0.519 \\
\hline Elevated insulin resistance & 23 & 95.8 & 16 & 100 & $39(97.5 \%)$ & 0.684 & 0.408 \\
\hline
\end{tabular}


Table (11): Tissue Doppler Imaging (TDI) data among NAFLD children and adolescents in relation to their degree of hepatic steatosis.

\begin{tabular}{|c|c|c|c|c|}
\hline \multirow{2}{*}{$\begin{array}{l}\text { Echocardiology } \\
\text { (Tissue Doppler Imaging) } \\
\text { (TDI) data }\end{array}$} & \multicolumn{2}{|c|}{$\begin{array}{l}\text { TDI data among NAFLD children } \\
\text { and adolescents in relation to their } \\
\text { degree of hepatic steatosis }(n=40)\end{array}$} & \multirow[b]{2}{*}{$t$-test } & \multirow[b]{2}{*}{$p$} \\
\hline & $\begin{array}{c}\text { Mild } \\
(\text { Grade I) } \\
(\mathrm{n}=24) \\
\text { Mean } \pm \text { SD }\end{array}$ & $\begin{array}{l}\text { Moderate \& severe } \\
\text { (Grade II \& III) } \\
(\mathrm{n}=16) \\
\text { Mean } \pm \text { SD }\end{array}$ & & \\
\hline Mitral annulus systolic velocity (S) & $6.87 \pm 0.95$ & $6.75 \pm 0.68$ & 0.454 & 0.652 \\
\hline $\mathrm{E}^{\prime} / \mathrm{A}^{\prime}$ ratio & $1.60 \pm 0.27$ & $1.61 \pm 0.20$ & 0.027 & 0.979 \\
\hline Myocardial Performance Index (MPI) & $0.54 \pm 0.18$ & $0.60 \pm 0.11$ & 1.109 & 0.274 \\
\hline Left ventricular mass (LV Mass) & $100.58 \pm 14.10$ & $112.00 \pm 19.13$ & 2.174 & $0.036^{*}$ \\
\hline
\end{tabular}

\section{Discussion}

Most recent studies are conflicting and do not support an independent relation between NAFLD and CVD in pediatric patients. Despite that, some findings have shown that atherosclerosis is an early process beginning in childhood, as demonstrated by early subclinical atherosclerosis [flow-mediated vasodilatation; FMD, carotid artery intimal medial thickness (cIMT), arterial stiffness] and abnormalities in myocardial structure and function including LV dysfunction, increased LV mass, and epicardial adipose tissue thickness (EAT)) observed in obese children and adolescents [13]

The presence of intracellular cardiac troponin subunits T and I (cTnT and cTnI) in the blood is a sensitive and specific indicator for myocardial injury $[14,15]$.

New noninvasive myocardial imaging including tissue Doppler (TDI), have been studied in evaluation of cardiac insult in systemic diseases $[16,17]$

In this study the mean values of age were significantly higher in obese patients with NAFLD compared to controls and there was insignificant male predominance. However, significant differences were reported in the prevalence of NAFLD in boys compared to girls, with boys having a higher prevalence $(66.67 \%)$ in the SCALE study. In partial agreement with our results, Schwimmer et al., [18] suggested that NAFLD is consistently more prevalent in boys than in girls signifying that sex hormones are associated with the occurrence of pediatric NAFLD that is more prevalent in adolescents than in younger children where sex hormones and IR at puberty may be the cause of this finding. The disparate result of our study may be due to differences in selection criteria for enrollment.

The mean values of other anthropometric measures (weight, waist circumference and BMI) were significantly higher in obese children with and without NAFLD compared to controls. This finding is attributed to our selection criteria. But the finding of no differences between obese patients with and those without NAFLD in this study is not in agreement with that reported by Lee et al., [19] who found that NAFLD patients were more likely to be obese ( $58 \%$ vs. $16 \%)$ where measures of visceral and subcutaneous fat area, waist and hip circumferences are increased compared to those without NAFLD [19]. Our disparate result could be attributed to comparability of our obese patients (whether with or without NAFLD) in anthropometric measures.

NAFLD and obese patients had high WC exceeding the 95 th percentile. WC is considered a surrogate measure of visceral fat and may predict the development of NAFLD in children [20] and it has been found to be associated with several metabolic impairments, including IR and NAFLD severity [20,21] .

Frequency of patients with acanthosis nigricans was significantly higher in obese children and adolescent with NAFLD compared to those without NAFLD. This finding agreed with that reported by Louthan et al., [22] who observed acanthosis nigricans (a clinical marker of hyperinsulinemia) in one-third of the children with biopsy-proven NAFLD.

In the present study, the mean values of diastolic blood pressure were higher in NAFLD patients compared to controls whereas mean values of systolic blood pressure showed no significant difference between patients and controls. This finding partially agreed with that reported by Lee et al., [19] and Shwimmer et al., [23] who demonstrated that children with NAFLD. Obesity predisposes to hypertension because of metabolic and hemodynamic abnormalities, leading to inadequate lowering of systemic resistance and, to a more severe cardiovascular burden [24] . 
In the present study, the mean values of ALT and GGT were significantly higher in patients compared to controls. This could be due to presence of some degree of hepatic inflammatory reaction in children with NAFLD. This finding agreed with that reported by Lee et al., [19] .

In this study, the mean levels of total serum cholesterol, Triglycerides (TG) and (LDL-C) were significantly higher in patients compared to controls, whereas mean levels of HDL-C were significantly lower in patients compared to controls. The dyslipidemic profile detected in the NAFLD patients of this study agreed with that reported by Romero et al., [25] and Sert et al., [26] who found higher levels of total cholesterol and LDL-C and lower levels of HDL-C in patients with NAFLD compared to patients without NAFLD. This is due to several metabolic impairments, including IR and NAFLD severity [20,21] .

In this study, there is semi-parallel increase in the percentage of cases with abnormal laboratory data including dyslipidemic profile, with advancing degree of hepatic echogenicity. This result is in agreement with that reported by Duarte and Silva who found that the prevalence of hypercholesterolemia and hypertriglyceridemia was associated with the degree of steatosis [21]. These findings could be explained by the previous detection of severe metabolic impairments among overweight and obese children with NAFLD than those without NAFLD although unfavorable lipid profile was found in children with BMI greater than 85 th percentile for age [27]. In this study the mean values of fasting serum insulin level and HOMA-IR were higher in obese patients (with and without NAFLD) compared to controls. This findings agreed with that reported by Sert et al., [26] who found that the NAFLD obese group had significantly higher HOMA-IR values than the non-NAFLD and control groups. Insulin resistance had a significant independent impact on LV remodeling in the absence of diabetes mellitus in patients with NAFLD.

It is well-established that the metabolic syndrome and insulin resistance affect LV geometry and function [28]. The presence of IR altered the cardiac structure and contractile function at the level of the myocyte in an animal study [29]. This finding has been also demonstrated in humans [28] Whether or not the IR is independently associated with cardiac remodeling is unknown. Iacobellis et al., [28] reported that IR in obesity in the absence of diabetes was associated with an increased LVM and changes in LV geometry. However, not all studies in the non-diabetic population supported their results. When adjusted for BMI and BP, IR was not an independent determinant of LVM [30]

There is limited data on the influence of the metabolic syndrome on LV function, especially in patients without hypertension, diabetes, and obesity. A slight increase in plasma glucose levels was associated with abnormal diastolic function, independent from LV hypertrophy in non-diabetic patients with treated hypertension [30]. The effect of the metabolic syndrome on the LV diastolic function has also been demonstrated in the Strong Heart Study [31]. Changes in LV geometry and function correlated well with BMI in the previous studies that included patients with marked obesity. Recently, two studies in obese populations revealed that decreased systolic and early diastolic velocities on TDI and BMI were the only predictors of LV systolic and diastolic dysfunction [32,33]

Our study showed that there was no significant difference between patients and controls as regard the mean values of serum troponin I whereas the study reported by Elsaidi, et al., 2017 [34] demonstrated that troponin I showed a marked significant elevation in obese patients compared with controls. The difference between both studies could be attributed to patients characteristics, differences in methods of assay of troponin I in both studies and severity of NAFLD in both studies where patients in our study mostly belong to the mild grades of the disease (grades I and II as detected by abdominal ultrasound). Also, Elsaidi, et al., 2017 [34] and Di Salvo et al., [35] found no correlation between troponin I and LV diastolic function.

The conventional indices of global LV systolic and diastolic function, like EF and volumes have some disadvantages. These are load dependency, measurement errors, and insufficient image quality. TDI is another useful echocardiographic technique employing the Doppler principle to measure the velocity of myocardial segments and other cardiac structures which is load independent. But TDI also has some limitations, like angle dependency of the ultrasound beam, the complex rotational and translational movements of the heart [36]

Using TDI our study showed significant increase in mean values of LV myocardial performance index in NAFLD patients compared to controls. Sert et al., [26] found that non-NAFLD and NAFLD obese groups had regional systolic and/or diastolic myocardial functional abnormalities in the interventricular septum and LV lateral wall. In the basal, mid septal and mid lateral LV walls, the non-NAFLD and NAFLD obese groups had higher MPI values than the controls. 
Reductions in indexes of systolic function were found only in patients with a considerable degree of obesity, suggesting that LV systolic function is affected late in the course of obesity [37]. In our study, no patient had LV systolic dysfunction by conventional echocardiography. We found abnormalities in LV structure, including increased LV wall thickness, LV mass, and LV mass index, in obese adolescents with NAFLD. Our study also provides evidence that obese adolescents with NAFLD exhibit abnormalities of LV structure and function (increased LV dimensions and LV mass as well as diastolic dysfunction) that can be identified by PW TDI. Our study is the first to show subtle LV dysfunction by pulsed-wave TDI, which conventional echocardiography cannot detect in obese adolescents with NAFLD.

In our study there was also significant increase in LV mass in obese children and adolescents with NAFLD compared to the controls. Previous studies showed a similar result which have shown that NAFLD has been associated with increased LV mass and changes in the cardiac geometry [38-40] Goland et al., [40] reported that normotensive, nondiabetic patients with NAFLD in the absence of morbi d obesity, hypertension, and diabetes have mildly altered geometry (higher thickening of the intraventricular and posterior wall, increased LV mass indexed to height). However, they found that the EF and systolic velocities on tissue Doppler imaging were similar between groups. In addition, Fotbolcu et al., [39] showed that LV mass index, interventricular septum, and posterior wall thickness were higher in normotensive, nondiabetic NAFLD patients than normal individuals. They found significant systolic dysfunction detected by TDI in NAFLD patients, although ventricular dimensions and $\mathrm{EF}$ of the two groups were similar.

To summarize, multiple mechanisms contribute to LV dysfunction in obesity, including lipotoxicity associated with cardiac steatosis and lipoapoptosis, alterations in fatty acid metabolism, overproduction of cardioinhibitory cytokines, up-regulation of some neurohormones (especially angiotensin II), myocardial fibrosis and chronic overload with LV dilatation and hypertrophy, and increased oxygen consumption $[41,42]$. Insulin resistance may represent a link between obesity and LV dysfunction. Elevated insulin levels in patients with IR stimulate myocyte growth and interstitial fibrosis. Insulin also causes sodium retention and activates the sympathetic nervous system which can affect cardiac performance $[\mathbf{4 2 , 4 3}$. It is well-established that the metabolic syndrome and insulin resistance affect LV geometry and function [28].
The limitations of this study included small sample size and lack of histological examination with subsequent inability to assess NAFLD severity. Further, although ultrasonography is a practical approach commonly used to detect hepatic steatosis, it is not the gold standard technique for quantitative liver fat and it has several limitations for detection of steatosis.

\section{Conclusion:}

Patients with NAFLD have evidence of subclinical myocardial dysfunction using TDI echocardiography. Although the TDI provides new insight into alterations in LV structure and function related to IR in NAFLD patients, it cannot be used for differentiation of steatosis grading.

\section{Acknowledgments:}

This research was carried out without funding.

\section{Conflicts of interest:}

No conflicts of interest declared.

\section{Authors' contributions:}

All authors had equal role in design, work, statistical analysis and manuscript writing. All authors have approved the final article work.

\section{References}

1- FELDSTEIN A.E., CHARATCHAROENWITTHAYA P., TREEPRASERTSUK S., et al.: The natural history of non-alcoholic fatty liver disease in children: A follow-up study for up to 20 years. Gut., 58 (11): 1538-44, 2009.

2- BALLESTRI S., LONARDO A., BONAPACE S., et al.: Risk of cardiovascular, cardiac and arrhythmic complications in patients with non-alcoholic fatty liver disease. WJG, 20 (7): 1724, 2014.

3- SÖDERBERG C., STÅL P., ASKLING J., et al.: Decreased survival of subjects with elevated liver function tests during a 28-year follow-up. Hepatology, 51 (2): 595-602, 2010.

4- ONG J.P., PITTS A. and YOUNOSSI Z.M.: Increased overall mortality and liver-related mortality in nonalcoholic fatty liver disease. Journal of Hepatology, 49 (4): 608-12, 2008.

5- VILLANOVA N., MOSCATIELLO S., RAMILLI S., et al.: Endothelial dysfunction and cardiovascular risk profile in nonalcoholic fatty liver disease. Hepatology, 42 (2): 473-80, 2005

6- ASSY N., DJIBRE A., FARAH R., et al.: Presence of coronary plaques in patients with nonalcoholic fatty liver disease. Radiology, 254 (2): 393-400, 2010.

7- VÖLZKE H., ROBINSON D.M., KLEINE V., et al.: Hepatic steatosis is associated with an increased risk of carotid atherosclerosis. WJG, 11 (12): 18481853, 2005.

8- VanWAGNER L.B., NING H., LEWIS C.E., et al.: Associations between nonalcoholic fatty liver disease and subclinical atherosclerosis in middle-aged adults: The 
Coronary Artery Risk Development in Young Adults Study. Atherosclerosis, 235 (2): 599-605, 2014.

9- TARGHER G., DAY C.P. and BONORA E.: Risk of cardiovascular disease in patients with nonalcoholic fatty liver disease. New England Journal of Medicine, 363 (14): 1341-50, 2010.

10- LOPEZ L., COLAN S.D., FROMMELT P.C., et al.: Recommendations for quantification methods during the performance of a pediatric echocardiogram: A report from the Pediatric Measurements Writing Group of the American Society of Echocardiography Pediatric and Congenital Heart Disease Council. Journal of the American Society of Echocardiography, 23 (5): 465-95, 2010.

11-ABRAHAM T.P., DIMAANO V.L. and LIANG H.Y.: Role of tissue Doppler and strain echocardiography in current clinical practice. Circulation, 116 (22): 2597-609, 2007.

12- TEI C., NISHIMURA R.A., SEWARD J.B., et al.: Noninvasive Doppler-derived myocardial performance index: Correlation with simultaneous measurements of cardiac catheterization measurements. Journal of the American Society of Echocardiography, 10 (2): 169-78, 1997.

13- PACIFICO L., NOBILI V., ANANIA C., et al.: Pediatric nonalcoholic fatty liver disease, metabolic syndrome and cardiovascular risk. WJG, 17 (26): 3082-91, 2011.

14- THYGESEN K., ALPERT J.S. and WHITE H.D.: Universal definition of myocardial infarction. Journal of the American College of Cardiology, 50 (22): 2173-95, 2007.

15-WU A.H.: Interpretation of high sensitivity cardiac troponin I results: Reference to biological variability in patients who present to the emergency room with $\mathrm{c}$ hest pain: Case report series. Clinica Chimica Acta, 401 (1-2): 1704, 2009.

16- YU C.M., SANDERSON J.E., MARWICK T.H., et al.: Tissue Doppler imaging: A new prognosticator for cardiovascular diseases. Journal of the American College of Cardiology, 49 (19): 1903-14, 2007.

17- SPETHMANN S., DREGER H., SCHATTKE S., et al.: Two-dimensional speckle tracking of the left ventricle in patients with systemic sclerosis for an early detection of myocardial involvement. European Heart JournalCardiovascular Imaging, 13 (10): 863-70, 2012.

18- SCHWIMMER J.B., DEUTSCH R., KAHEN T., et al.: Prevalence of fatty liver in children and adolescents. Pediatrics, 118 (4): 1388-93, 2006.

19- LEE Y.H., KIM K.J., EUN YOO M., et al.: Association of non-alcoholic steatohepatitis with subclinical myocardial dysfunction in non-cirrhotic patients. Journal of Hepatology, 68 (4): 764-72, 2018.

20- BRAMBILLA P., BEDOGNI G., MORENO L., et al.: Cross validation of anthropometry against magnetic resonance imaging for the assessment of visceral and subcutaneous adipose tissue in children. International Journal of Obesity, 30 (1): 23-30, 2006.

21- DUARTE MAS and SILVA GAPD: Hepatic steatosis in obese children and adolescents. Jornal de Pediatria, 87 (2): 150-6, 2011.

22- LOUTHAN M.V., BARVE S., McCLAIN C.J., et al.: Decreased serum adiponectin: An early event in pediatric nonalcoholic fatty liver disease. The Journal of Pediatrics, 147 (6): 835-8, 2005.
23- SCHWIMMER J.B., ZEPEDA A., NEWTON K.P., et al.: Longitudinal assessment of high blood pressure in children with nonalcoholic fatty liver disease. PloS One, 9 (11): e112569, 2014.

24- PALMIERI V. and BELLA J.N.: Metabolic syndrome and left ventricular structure and functional abnormalities. American Journal of Hypertension, 19 (2): 206-7, 2006.

25- ROMERO-IBARGUENGOITIA M.E., VADILLOORTEGA F., CABALLERO A.E., et al.: Family history and obesity in youth, their effect on acylcarnitine/ aminoacids metabolomics and non-alcoholic fatty liver disease (NAFLD). Structural equation modeling approach. PloS One, 13 (2): e0193138, 2018.

26- SERT A., AYPAR E., PIRGON O., et al.: Left ventricular function by echocardiography, tissue Doppler imaging, and carotid intima-media thickness in obese adolescents with nonalcoholic fatty liver disease. The American Journal of Cardiology, 112 (3): 436-43, 2013.

27- FRIEDLAND O., NEMET D., GORODNITSKY N., et al.: Obesity and lipid profiles in children and adolescents. Journal of Pediatric Endocrinology and Metabolism, 15 (7): 1011-6, 2002.

28- IACOBELLIS G., RIBAUDO M.C., ZAPPATERRENO A., et al.: Relationship of insulin sensitivity and left ventricular mass in uncomplicated obesity. Obesity research, 11 (4): 518-24, 2003.

29- DUTTA K., PODOLIN D.A., DAVIDSON M.B., et al.: Cardiomyocyte dysfunction in sucrose-fed rats is associated with insulin resistance. Diabetes, 50 (5): 1186-92, 2001.

30- MIYAZATO J., HORIO T., TAKISHITA S., et al.: Fasting plasma glucose is an independent determinant of left ventricular diastolic dysfunction in nondiabetic patients with treated essential hypertension. Hypertension Research, 25 (3): 403-9, 2002.

31- CHINALI M., DEVEREUX R.B., HOWARD B.V., et al.: Comparison of cardiac structure and function in American Indians with and without the metabolic syndrome (the Strong Heart Study). The American Journal of Cardiology, 93 (1): 40-4, 2004.

32- WILLENS H.J., CHAKKO S.C., LOWERY M.H., et al.: Tissue Doppler imaging of the right and left ventricle in severe obesity (body mass index $>35 \mathrm{~kg} / \mathrm{m}^{2}$ ). The American Journal of Cardiology, 94 (8): 1087-90, 2004.

33- TANALP A.C., BITIGEN A., CEVIK C., et al.: The role of tissue Doppler study in the assessment of left ventricular dysfunction in obesity. Acta cardiologica, 63 (5): 541-6, 2008.

34- EL SAIEDI S.A., MIRA M.F., SHARAF S.A., et al.: Left ventricular diastolic dysfunction without left ventricular hypertrophy in obese children and adolescents: A Tissue Doppler Imaging and Cardiac Troponin I Study. Cardiology in the Young, 28(1): 76-84, 2018.

35- Di SALVO G., PACILEO G., DEL GIUDICE E.M., et al.: Abnormal myocardial deformation properties in obese, non-hypertensive children: An ambulatory blood pressure monitoring, standard echocardiographic, and strain rate imaging study. European Heart Journal, 27 (22): 268995, 2006. 
36- BAKT1R A.O., ŞARL1 B., ALTEKIN R.E., et al.: Non alcoholic steatohepatitis is associated with subclinical impairment in left ventricular function measured by speckle tracking echocardiography. Anatolian Journal of Cardiology, 15 (2): 137, 2015.

37- CHINALI M., De SIMONE G., ROMAN M.J., et al.: Impact of obesity on cardiac geometry and function in a population of adolescents: The Strong Heart Study. Journal of the American College of Cardiology, 47 (11): $2267-$ 73, 2006.

38- BONAPACE S., PERSEGHIN G., MOLON G., et al.: Nonalcoholic fatty liver disease is associated with left ventricular diastolic dysfunction in patients with type 2 diabetes. Diabetes Care, 35 (2): 389-95, 2012.

39- FOTBOLCU H., YAKAR T., DUMAN D., et al.: Impairment of the left ventricular systolic and diastolic function in patients with non-alcoholic fatty liver disease. Cardiology Journal, 17 (5): 457-63, 2010.
40- GOLAND S., SHIMONI S., ZORNITZKI T., et al.: Cardiac abnormalities as a new manifestation of nonalcoholic fatty liver disease: Echocardiographic and tissue Doppler imaging assessment. Journal of Clinical Gastroenterology, 40 (10): 949-55, 2006.

41- PETERSON L.R., HERRERO P., SCHECHTMAN K.B., et al.: Effect of obesity and insulin resistance on myocardial substrate metabolism and efficiency in young women. Circulation, 109 (18): 2191-6, 2004.

42- WONG C.Y., O'MOORE-SULLIVAN T., LEANO R., et al.: Alterations of left ventricular myocardial characteristics associated with obesity. Circulation, 110 (19): 3081-7, 2004.

43- Di BELLO V., SANTINI F., Di COЮ A., et al.: Obesity cardiomyopathy: Is it a reality? An ultrasonic tissue characterization study. Journal of the American Society of Echocardiography, 19 (8): 1063-71, 2006.

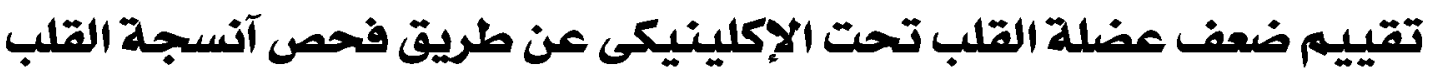 بالدوبلر فى الآطفال المصابين بمرض الحكينيكى الكبد الدهنى فير الكحولى آنسج}

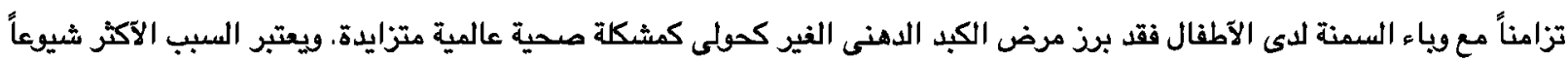

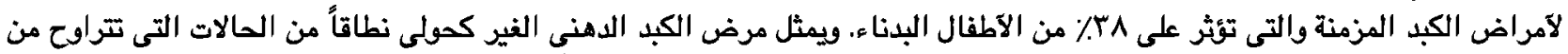

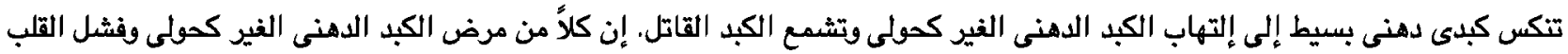

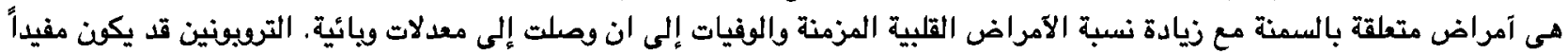

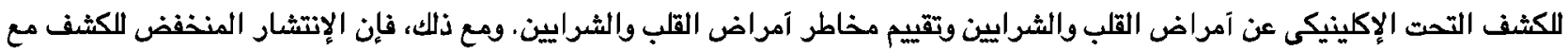
فحوصات القياسية يحد من فائدة قياس الترويونين لهذه التطبيقات السريرية.

الهدف من البحث: هو تقييم عضلة القلب تحت الإكلينيكى عن طريق فحص آنسجة القلب بالدوبلر فى الآطفال المصابين بمرض الكبد

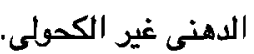

المرضى والطرق: هذه الدراسة قد آجريت على ك مجموعات من الآطفال. المجموعة الآولى تتكون من عدلد .ع من الآطفال البدناء وذائدىى

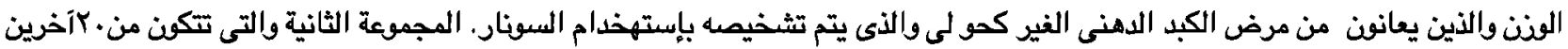

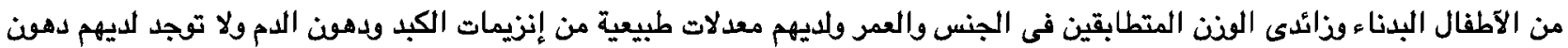

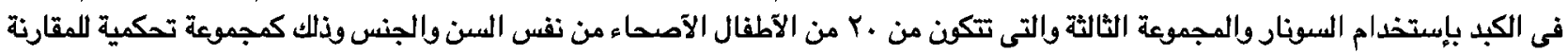

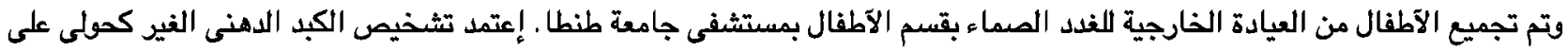

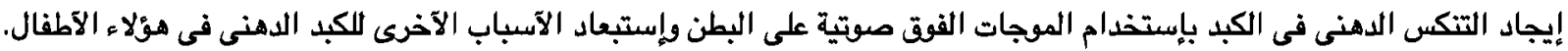

المعايير المدرجة: الآطفال والمراهقين الذين يعانون من السمنة وزيادة المذن البسيطة المصابون وغير المصابين بمرض الكبد الدهنى

$$
\text { غير الكصولى. }
$$

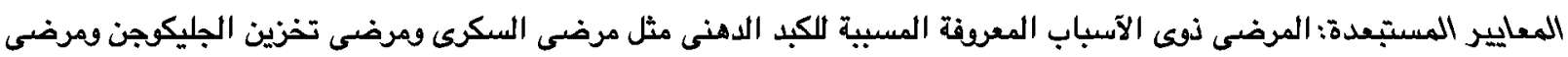

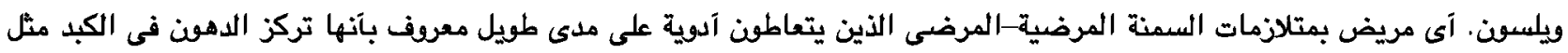

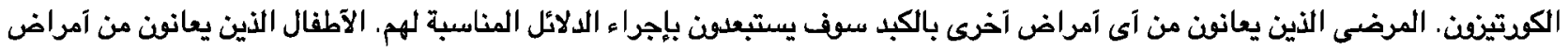

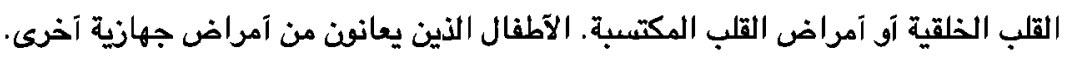

الطرق البحثيّة: المشاركن فى هذه الدراسة قد خضعوا للآتى: فحص إكلينيكى كامل وتاريخ مرضى كامل وفحص شامل آجرى لكل طفل

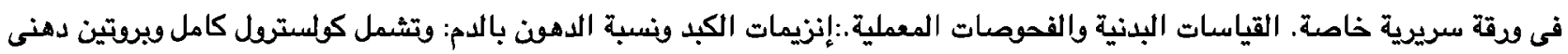


عالى الكثافة وبروتين دهنى منخفض الكثافة ودهون ثلاثية صائم - قياس مستوى السكر فى الدم (صاتم) قياس مستوى الآنسولين فى الدام

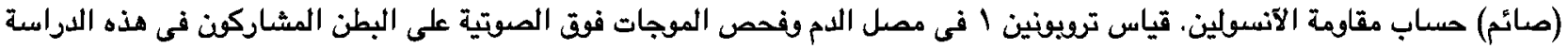

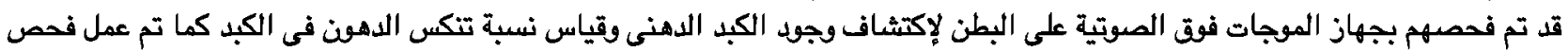

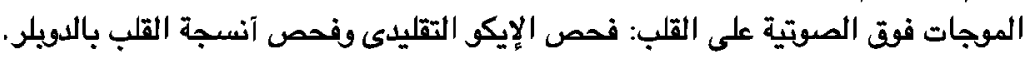

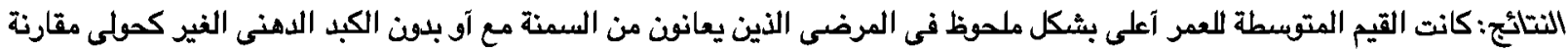

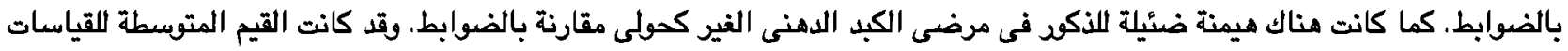

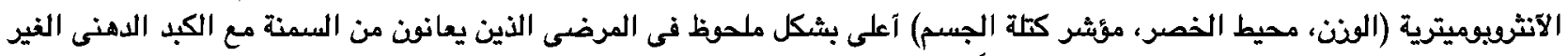

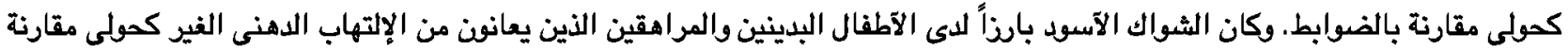

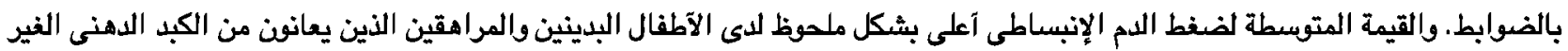
كحولى مقارنة بالضوابط.

إختبارات وظائف الكبد : متوسطات قيم إنزيمات الكبد ALT, GGT فى الدم آعلى بكثير ما بين المرضى والضوابط وكان فى ذلك دلالة

إحصائية.

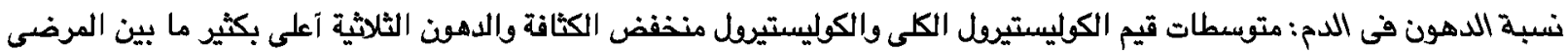

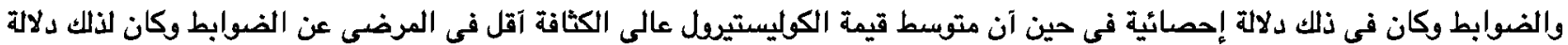

إحصائية آيضاً.

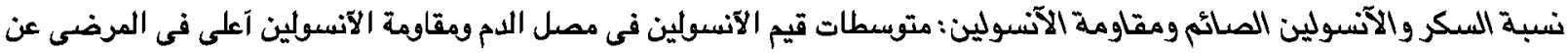

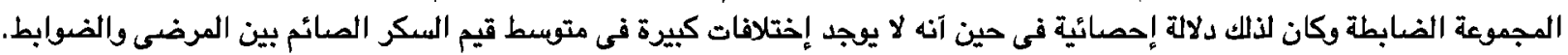

التروبونين 1: لا يوجد إختلاف كيير فى متوسط قيم الترويونين بين المرضى والضوابط - نتائج فحص الموجات فوق الصوتية على القلب:

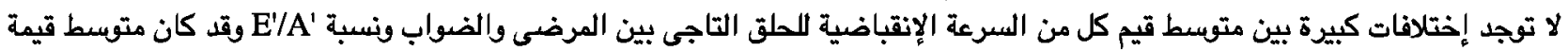

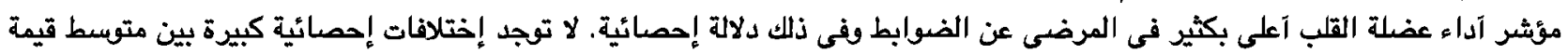

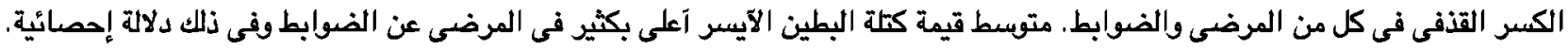

الإستتاج: تشير نتائج الدراسة إلى آن الآطفال والمراهقين الذين يعانون من الإلتهاب الكبد الدهنى الغير كعولى يعانون من ضعف تصت

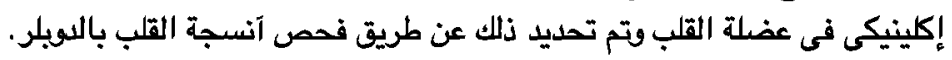

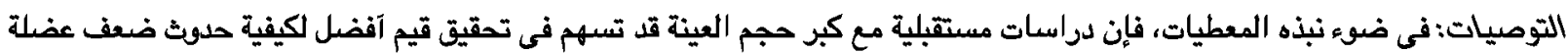

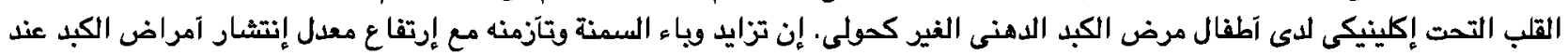

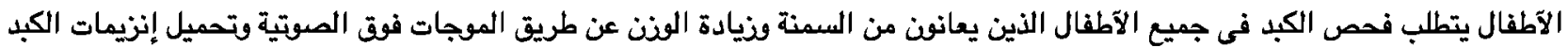

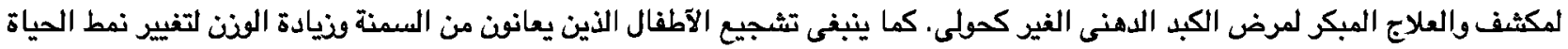

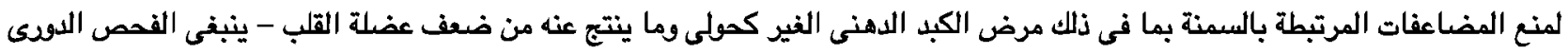

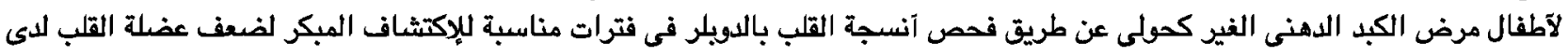

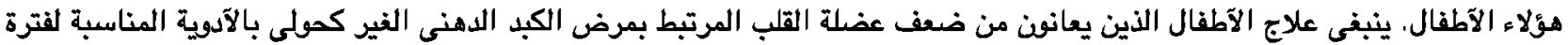
زمنية مناسبة لمنع حدوث مضاعفات آشال الشد خطودة. 